\title{
An Adenovirus Type 5 Gene Function Required for Initiation of Viral DNA Replication
}

\author{
PETER C. van DER VLIET AND JOHN S. SUSSENBACH \\ Laboratory for Physiological Chemistry. State University of Utrecht, Vondellaan 24a, Utrecht, The \\ Netherlands \\ Accepted May 16, 1975
}

\begin{abstract}
Adenovirus type 5 (Ad5) DNA replication was studied after infection of human or monkey cells with two DNA-negative temperature-sensitive mutants belonging to different complementation groups (H5ts125 and H5ts36). When infection was carried out at the permissive temperature $\left(32^{\circ}\right)$ followed by a shift to the nonpermissive temperature $\left(39.5^{\circ}\right)$ viral DNA synthesis in H5ts125-infected cells was reduced 90\% within $1 \mathrm{hr}$ after shift-up, while a decline in DNA synthesis in H5ts36-infected cells is only observed after $6 \mathrm{hr}$. Analysis of the various forms of DNA synthesized under conditions of inhibition showed a constant ratio of replicating to mature viral DNA for both mutants, while no accumulation of replicating molecules was observed.

When H5ts125-infected cells were pulse-labeled with $\left[{ }^{3} \mathrm{H}\right]$ thymidine at 32 or $39.5^{\circ}$ followed by a chase of the label at $39.5^{\circ}$, replicating DNA was converted into mature DNA at the same rate as in wild-type-infected cells. This indicates that chain propagation and termination could occur normally under nonpermissive conditions. The results of density labeling experiments performed at $39.5^{\circ}$ are in agreement with an initiation block in $\mathrm{H} 5$ ts125-infected cells at the nonpermissive temperature. It is concluded that the H5ts 125 gene product and possibly also the $\mathrm{H} 5 \mathrm{ts} 36$ gene product are required for the initiation of new rounds of replication. The potential role in initiation of the adenovirus-specific DNA binding protein, which is coded for by the H5ts125 gene, is discussed.
\end{abstract}

\section{INTRODUCTION}

Temperature-sensitive (ts) mutants of Ad5 have been divided into 17 complementation groups, which is one-third to onehalf of the total number of groups expected on the basis of the genome size (Williams et al., 1974). Most of the ts mutants characterized so far are defective in a late function, and only two groups of DNAnegative mutants have been isolated. Of these, one is represented only by a single mutant (H5ts125) and the other by three mutants, viz., H5ts36, H5ts37 and H5ts149.

Our knowledge concerning the phenotype of these mutants is limited. H5ts36 is defective in transformation at the nonpermissive temperature, while $\mathrm{H} 5 \mathrm{ts} 125$ transforms rat cells at a frequency higher than wild type (Williams et al., 1974; Gins- berg et al., 1974). Genetic dominance studies have shown that the $\mathrm{H} 5 \mathrm{ts} 125$ gene product is required in stoichiometric amounts for virus production, while for the H5ts36 gene product catalytic amounts are sufficient (Austin, Young and Williams, unpublished results). Recently, the H5ts125 gene product has been characterized as a DNA binding protein on the basis of the thermolability of this adenovirus-specific protein in H5ts125-infected cells (van der Vliet et al., 1975). This DNA binding protein, with a molecular weight of 72,000 , is made in large amounts, up to $10^{7}$ copies per infected cell. Synthesis starts early in infection and is independent of viral or cellular DNA synthesis. In vitro, the protein binds preferentially to single-stranded, not to double-stranded, DNA (van der Vliet and Levine, 1973). 
In order to investigate during which step of the viral DNA replication this protein is required, the phenotype of H5ts 125 has been studied. It will be shown that initiation of new rounds of replication but not chain propagation or termination is blocked in H5ts125-infected cells at the nonpermissive temperature. In addition, evidence will be presented suggesting that the H5ts36 gene function may also be required for initiation.

\section{MATERIALS AND METHODS}

Growth of cells and viruses. Human KB cells were grown in monolayer as described earlier (Sussenbach and van der Vliet, 1972). Primary African green monkey kidney (AGMK) cells were cultivated in Dulbecco's modified Eagle's medium. H5ts $125,{ }^{1}$ originally isolated by Finsinger and Ginsberg (1972), was kindly supplied by Dr. H. S. Ginsberg and H5ts36 by Dr. J. F. Williams. Mutant viruses were propagated at $32^{\circ}$ and purified as described (van der Vliet and Sussenbach, 1972).

Pulse-chase experiments and the isolation of pulse-labeled viral DNA. KB cells $\left(5 \times 10^{5} / \mathrm{ml}\right)$ in suspension were infected at a multiplicity of 2000 physical particles per cell in Eagle's medium containing $20 \mathrm{mM}$ $N$-2-hydroxyethyl piperazine- $N^{\prime}$-2-ethane sulfonic acid (HEPES), pH 7.2. In some cases, $\left[{ }^{14} \mathrm{C}\right]$ thymine $(0.5 \mu \mathrm{Ci} / \mathrm{ml})$ was added at $16 \mathrm{hr}$ postinfection to prelabel viral DNA. The cells were pulse-labeled with $\left[{ }^{3} \mathrm{H}\right]$ thymidine $(30 \mu \mathrm{Ci} / \mathrm{ml})$ at a concentration of $5 \times 10^{6}$ cells $/ \mathrm{ml}$. For pulsechase experiments, nonradioactive thymidine, up to $1 \mathrm{mM}$, was added, and the cells were washed three times at the indicated temperature with prewarmed medium containing $1 \mathrm{~m} M$ thymidine and suspended in medium containing $0.25 \mathrm{~m} M$ thymidine. At appropriate times, samples were mixed with an equal volume of phosphate-buffered saline containing $10 \mathrm{mM}$ EDTA and 1 $\mathrm{m} M$ thymidine at $4^{\circ}$.

To isolate viral DNA, cells were washed three times with $0.01 M$ Tris- $\mathrm{HCl}(\mathrm{pH}$ 8.1)/0.01 $M$ EDTA and suspended in this

' Abbreviations have been used according to the proposed nomenclature for adenovirus mutants (Ginsberg et al., 1973). buffer at a concentration of $3 \times 10^{6}$ cells/ $\mathrm{ml}$. Sodium dodecylsulfate (SDS) was added to $0.1 \%$ and Pronase to $0.5 \mathrm{mg} / \mathrm{ml}$. After $15 \mathrm{~min}$ at $30^{\circ}$, the SDS concentration was raised to $2 \%$ and, after $2 \mathrm{~min}, \mathrm{NaCl}$ was added to a concentration of $1 M$. After $16 \mathrm{hr}$ at $4^{\circ}$, the suspension was centrifuged for $30 \mathrm{~min}$ at $20,000 \mathrm{~g}$ and the supernatant fluid (called $1 \mathrm{M} \mathrm{NaCl}$ supernatant) was either dialyzed against $0.15 \mathrm{M} \mathrm{NaCl} / 0.015$ $M \mathrm{Na}$ citrate or used directly. Using this method, more than $90 \%$ of the total radioactivity incorporated during short (5 $\mathrm{min})$ or long (up to $5 \mathrm{hr}$ ) pulses with $\left[{ }^{3} \mathrm{H}\right]$ thymidine was found in the $1 \mathrm{M} \mathrm{NaCl}$ superna tant, indicating a high recovery of replicating as well as mature Ad5-DNA. DNA from purified Ad5 virions was isolated according to van der Eb et al. (1969).

Analysis of viral DNA. Band sedimentation was performed in $5-27 \%$ isokinetic sucrose gradients, containing $0.01 \mathrm{M}$ Tris-HCl ( $\mathrm{pH}$ 8.1)/0.001 $M$ EDTA / $M$ $\mathrm{NaCl} / 0.1 \%$ Sarkosyl. Techniques for buoyant density equilibrium centrifugation in $\mathrm{CsCl}$ have been described (van der Vliet and Sussenbach, 1972). When indicated, fractions were spotted on Whatmann 3MM filter disks, and the DNA was precipitated with $10 \%$ trichloroacetic acid (TCA). The filters were washed twice with $10 \%$ TCA, once with acetone, dried and counted in a liquid scintillation counter.

The complementary strands of Ad5DNA were separated using the poly $(\mathrm{U}, \mathrm{G})$ procedure as described by Tibbetts et al. (1974). A suitable batch of poly(U, G) was kindly supplied by Dr. L. Philipson. The light strand obtained after density centrifugation in neutral $\mathrm{CsCl}$ in the presence of $\operatorname{poly}(\mathrm{U}, \mathrm{G})$ was identical to the strand with the higher density in alkaline $\mathrm{CsCl}$ density gradients. This strand will therefore be called the $\mathrm{H}$-strand in this paper, in agreement with previously used nomenclature (Sussenbach et al., 1973). DNA-DNA hybridization was performed according to Aloni et al. (1969).

\section{RESULTS}

When cells were infected at $39.5^{\circ}$ with H5ts 36 or H5ts 125 and the cultures were kept at $39.5^{\circ}$ for the entire period of 
infection (16-20 hr), viral DNA synthesis was inhibited for more than $98 \%$ compared to wild-type-infected cultures (Ensinger and Ginsberg, 1972; Wilkie et al., 1973; van der Vliet et al., 1975). To study whether the two gene products are directly (or indirectly) involved in viral DNA replication, temperature shift-up experiments are required.

Kinetics of Shut-off of Viral DNA Synthesis After a Shift-up to the Nonpermissive Temperature

$\mathrm{KB}$ cells were infected at $32^{\circ}$ for $40 \mathrm{hr}$ with mutant or wild-type adenovirus, and the cultures were subsequently shifted to $39.5^{\circ}$ or kept at $32^{\circ}$. At the same time $\left[{ }^{3} \mathrm{H}\right]$ thymidine was added, and viral DNA synthesis was measured after various periods of time (Fig. 1). Wild-type- or H5ts36-infected cells continue to synthesize viral DNA for at least $4 \mathrm{hr}$ after the shift, the rate of $39.5^{\circ}$ being $1.6-2.1$ times that at $32^{\circ}$ (Figs. $1 \mathrm{C}$ and D). In H5ts 125 infected cultures however, DNA synthesis declines rapidly after about $30 \mathrm{~min}$ (Fig. 1A). The inhibition occurs equally well whether studied early $(20 \mathrm{hr})$ or late $(44 \mathrm{hr})$ after infection. Prelabeled viral DNA was not broken down after the shift-up, indicating that the decline in incorporation was not caused by a combination of normal synthesis and extensive breakdown of synthesized DNA (data not shown).

Inhibition of protein synthesis by cycloheximide did not change the results obtained with H5ts125 (Fig. 1B). Viral DNA synthesis under permissive conditions was independent of concomitant protein synthesis, in agreement with previous reports (Horwitz et al., 1973; Yamashita and Green, 1974). Similarly the decline in Ad5-DNA synthesis in H5ts125-infected cells after the shift to $39.5^{\circ}$ occurred normally in the absence of protein synthesis. This suggests that the cessation of viral DNA synthesis results directly from inactivation of the thermosensitive $\mathrm{H} 5 \mathrm{ts} 125$ protein. This is a strong indication that the H5ts125 gene product itself is required for viral DNA replication.

After incubation of $\mathrm{KB}$ cells at $39.5^{\circ}$ for periods longer than $4 \mathrm{hr}$, we observed a decline in viral DNA synthesis in wildtype- and H5ts36-infected cells. Therefore,

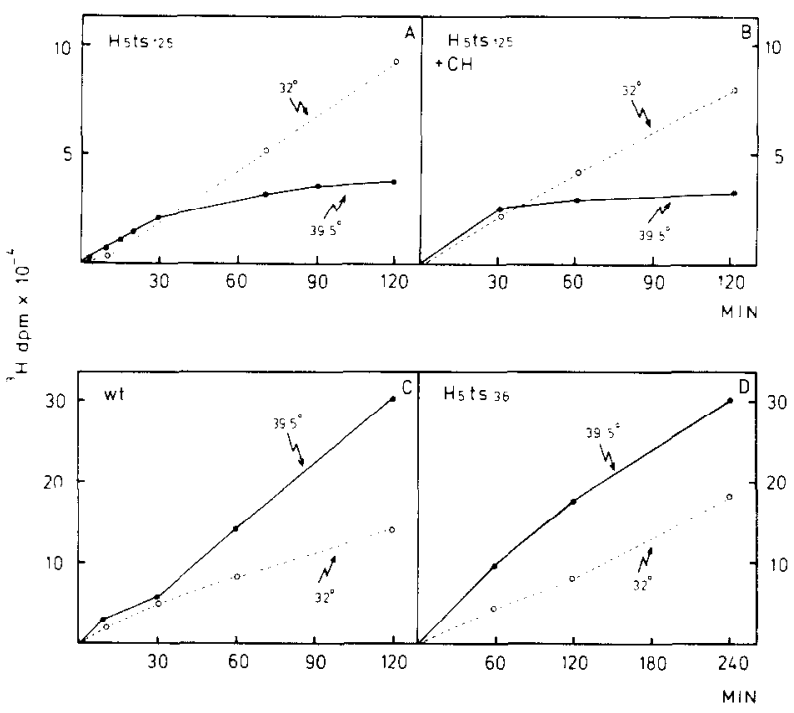

FIG. 1. Kinetics of viral DNA synthesis in infected $\mathrm{KB}$ cells after a shift from 32 to $39.5^{\circ}$. $\mathrm{KB}$ cells in suspension were infected with $\mathrm{H} 5 \mathrm{ts} 125, \mathrm{H} 5 \mathrm{ts} 36$ or wild type for $40 \mathrm{hr}$ at $32^{\circ}$. Half of the suspension was brought to $39.5^{\circ}$, and the remaining cells were further incubated at $\left.32^{\circ} .{ }^{3} \mathrm{H}\right]$ thymidine was added directly after the shift $(t=0)$, and viral DNA was isolated at the times indicated. Samples from the $1 M \mathrm{NaCl}$ supernatant, containing DNA from $5 \times 10^{4}$ cells, were precipitated with TCA and counted. Separate analysis of the isolated DNA in $\mathrm{CsCl}$ density gradients showed that all radioactive label was present in viral DNA. (A), H5ts125-infected cells; (B), H5ts125-infected cells to which $100 \mu \mathrm{g} / \mathrm{ml}$ of cycloheximide was added at $t=0$, causing a $95 \%$ inhibition of protein synthesis; (C), Wild-type-infected cells; (D), H5ts36-infected cells; note the difference in time scale. 
we also studied AGMK cells using short pulses at different times after a shift to $39.5^{\circ}$ (Fig. 2). As expected, the capacity to synthesize H5ts125 DNA slows down rapidly. In H5ts36-infected cells a decline is observed after $6 \mathrm{hr}$, while wild type still goes on. Similar results have been obtained by Levine et al. (1974). The slow response of $\mathrm{H} 5 \mathrm{ts} 36$-infected cells to a shift-up to the nonpermissive temperature is a considerable disadvantage for detailed analysis of this mutant. Most of our further studies have therefore been limited to H5ts125.

\section{Reversibility of the H5ts125 Block}

In H5ts125-infected cultures, shift-down experiments were performed to obtain information on the reversibility of the inhibition. AGMK cells were incubated for $40 \mathrm{hr}$ at $32^{\circ}$ and subsequently shifted to $39.5^{\circ}$. Cycloheximide $(100 \mu \mathrm{g} / \mathrm{ml})$ was added, and at various times the cultures were brought back to $32^{\circ}$ for $15 \mathrm{~min}$, followed by a 15 -min pulse with $\left[{ }^{3} \mathrm{H}\right]$ thymidine at that temperature. At $1 \mathrm{hr}$ after shift-up the $10 \%$ residual DNA synthesis at $39.5^{\circ}$ could be

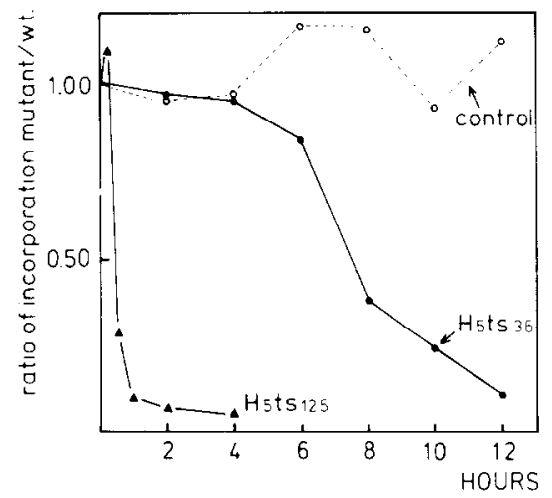

FIG. 2. Capacity of AGMK cells to synthesize viral DNA after a shift-up to the nonpermissive temperature. Mutant- or wild-type-infected AGMK cells in monolayer were incubated at $32^{\circ}$ for $40 \mathrm{hr}$, followed by transfer to $39.5^{\circ}$. At the indicated times part of the cultures were pulse-labeled with $\left[{ }^{3} \mathrm{H}\right]$ thymidine for 5 min (H5ts125) or $30 \mathrm{~min}$ (H5ts36). Pulse-labeled viral DNA was isolated and appropriate samples of the $1 M$ $\mathrm{NaCl}$ supernatant were precipitated with TCA and counted. The results are expressed as the ratio of incorporation of mutant to wild type and the ratio at $t$ $=0$ was set at 1.00 . The control represents the ratio of incorporation of $\mathrm{H} 5 \mathrm{ts} 36$ to wild type from cultures that were kept at $32^{\circ}$ during the entire period. restored to $83 \%$ by a shift-down, while $3 \mathrm{hr}$ later a restoration from 6 to $39 \%$ was still possible. This means that the inactivation was readily reversible even in the absence of protein synthesis, suggesting an excess pool of thermolabile H5ts 125 protein that could be easily reactivated at $32^{\circ}$ and that, in the absence of protein synthesis, is only slowly diminished below the level required for viral DNA synthesis.

\section{Analysis of H5ts125 DNA Synthesized After a Shift-up to the Nonpermissive Temperature}

Replicating adenovirus DNA contains extended regions of single-stranded DNA and can be separated from mature viral DNA using either sedimentation in neutral sucrose gradients or buoyant density equilibrium centrifugation in $\mathrm{CsCl}$ (Pearson and Hanawalt, 1971; Sussenbach and van der Vliet, 1972; Bellett and Younghusband, 1972; van der Eb, 1973; Pettersson, 1973). Pulse-labeled replicating DNA sediments faster than mature DNA in neutral sucrose gradients, with sedimentation values ranging from $31 \mathrm{~S}$ (mature Ad5-DNA) up to about $65 \mathrm{~S}$. Its buoyant density is $5-10$ $\mathrm{mg} / \mathrm{ml}$ higher than mature viral DNA ( $\rho=$ $\left.1.716 \mathrm{~g} / \mathrm{cm}^{3}\right)$.

These properties of pulse-labeled DNA have been used to determine the amount of replicating intermediates in $\mathrm{H} 5 \mathrm{ts} 125$ infected cells following a shift-up in temperature. AGMK cells, infected at $32^{\circ}$, were pulse-labeled for $5 \mathrm{~min}$ at $39.5^{\circ}$ at various times after the shift-up. Viral DNA synthesis is reduced rapidly but does not stop completely even $2 \mathrm{hr}$ after the shift-up (Fig. 2) . A residual synthesis of about 3-5\% is always observed. The viral DNA was isolated and subjected to neutral sucrose gradient sedimentation analysis and $\mathrm{CsCl}$ density centrifugation in the presence of ${ }^{32} \mathrm{P}$-labeled mature viral DNA.

The results obtained with two samples, 15 and $60 \mathrm{~min}$ after the shift from 32 to $39.5^{\circ}$, respectively, are shown in Fig. 3. Although in the 60-min sample DNA synthesis is reduced tenfold, the gradient profiles of both samples are very much the same and the ratio of replicating to mature DNA does not differ significantly. 


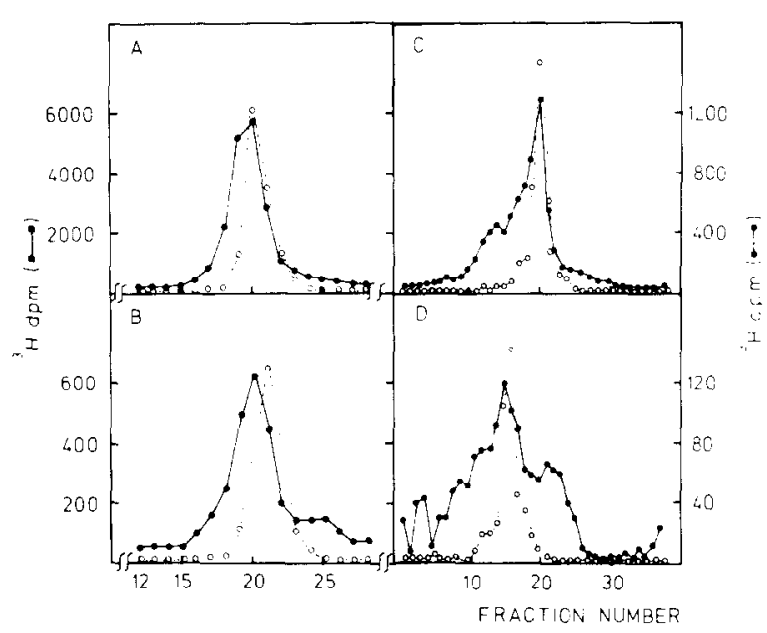

FIG, 3. Sucrose gradient sedimentation and $\mathrm{CsCl}$ equilibrium density centrifugation of H5ts125 DNA pulse-labeled under restrictive conditions. DNA samples from the experiment described in Fig. 2, labeled 15-20 $\min (A, C)$ or $60-65 \mathrm{~min}(B, D)$ after shift-up, were analyzed in the presence of ${ }^{32} \mathrm{P}$-labeled mature Ad5-DNA $(\mathrm{O}-\mathrm{O})$. (A, B), $\mathrm{CsCl}$ density gradient profiles. The samples contained DNA isolated from $5 \times 10^{6}$ cells. The density difference was $0.005 \mathrm{~g} / \mathrm{cm}^{3}$ per fraction. Fractions were collected and counted directly $\left({ }^{3} \mathrm{H} \mathrm{dpm}\right.$, - - (C, D), Sucrose gradient profiles. The samples contained DNA isolated from $2 \times 10^{6}$ cells. Sedimentation was from right to left. Fractions were precipitated with TCA and counted ( ${ }^{3} \mathrm{H} \mathrm{cpm}$.

A small amount of cellular DNA $(\rho=$ $1.700 \mathrm{~g} / \mathrm{cm}^{3}$ ) was observed in the $\mathrm{CsCl}$ gradients (Figs. 3A and B, fractions 24-46), presumably due to the presence of low molecular weight cellular DNA which was not removed during the extraction procedure. Some slower sedimenting (20-25 S) DNA was observed during sucrose gradient analysis, most markedly in the 60-min sample (Fig. 3D). This slower-sedimenting DNA consisted partly (35\%) of cellular and partly $(65 \%)$ of viral DNA, as determined by $\mathrm{CsCl}$ equilibrium centrifugation of the 20-25 S DNA following preparative sucrose gradient centrifugation (data not shown). This indicates some breakdown of viral molecules at $39.5^{\circ}$.

The percentage of pulse-labeled replicating DNA for each sample was calculated from sucrose gradient sedimentation analysis and $\mathrm{CsCl}$ density gradient analysis and is summarized in Table 1. The two separation methods gave different amounts of replicating DNA, with lower values obtained in the case of $\mathrm{CsCl}$ gradients due to the lower sensitivity of this method in separating single-stranded and doublestranded DNA. It is clear, however, that accumulation of replicating DNA did not occur even when viral DNA synthesis was inhibited more than $90 \%$.

These results suggest that chain propagation is not inhibited in $\mathrm{H} 5$ ts 125 -infected cells at the restrictive temperature and that the cessation of viral DNA replication might be caused by a reduction in the number of molecules that initiate new replication rounds. The residual synthesis after shift-up may be due to the survival of a small amount of functional $\mathrm{H} 5 \mathrm{ts} 125$ protein in the cell, even at $39.5^{\circ}$, which gives rise to a reduced amount of normal progeny H5ts125 DNA.

This notion is confirmed by hybridization experiments of newly synthesized H5ts125 DNA with the separated complementary strands of Ad5-DNA. The DNA synthesized in H5ts125-infected cells at the nonpermissive temperature hybridized to both the $\mathrm{H}$ - and L-strands, similar to DNA synthesized under permissive conditions, as illustrated in Table 2.

\section{Completion of Replication Rounds in H5ts125-Infected Cells at the Nonper- missive Temperature}

To test whether replication, once started at $32^{\circ}$, could be completed normally at 
TABLE 1

Amount of Replicating DNA in H5ts125-Infected Cells Pulse-Labeled for 5 Min at Various Times After a Shift-up to the NONPERMISSIVE 'I'EMPERATURE ${ }^{a}$

\begin{tabular}{|c|c|c|c|}
\hline \multirow{2}{*}{$\begin{array}{c}\text { Time } \\
\text { after } \\
\text { shift-up } \\
\text { to } \\
39.5^{\circ} \\
\text { (min) }\end{array}$} & \multirow{2}{*}{$\begin{array}{l}\text { Ratio of } \\
{\left[{ }^{3} \mathrm{H}\right]} \\
\text { thymidine } \\
\text { incor- } \\
\text { porated, } \\
\text { ts/wt }\end{array}$} & \multicolumn{2}{|c|}{ replicating DNA $(\%)$} \\
\hline & & $\begin{array}{l}\text { DNA } \\
>31 \mathrm{~S}\end{array}$ & $\begin{array}{c}\mathrm{DNA} \\
>1.716 \\
\mathrm{~g} / \mathrm{cm}^{3}\end{array}$ \\
\hline 0 & 1.00 & 66 & 36 \\
\hline 15 & 1.10 & 60 & 29 \\
\hline 30 & 0.31 & 53 & 35 \\
\hline 60 & 0.10 & 67 & 32 \\
\hline 120 & 0.08 & 63 & 39 \\
\hline 240 & 0.06 & 66 & 28 \\
\hline $\begin{array}{l}\text { Wild type } \\
(240)\end{array}$ & - & 65 & 31 \\
\hline
\end{tabular}

${ }^{a}$ AGMK cells were infected at $32^{\circ}$ for $44 \mathrm{hr}$ and then shifted to $39.5^{\circ}$. Cells were pulse-labeled for 5 min with $\left[{ }^{3} \mathrm{H}\right]$ thymidine at $39.5^{\circ}$ at the indicated time. The DNA was centrifuged in neutral sucrose gradients in the presence of ${ }^{2} \mathrm{P}$-labeled Ad5-DNA and the percentage of total $\left[{ }^{3} \mathrm{H}\right] \mathrm{DNA}$ sedimenting faster than the marker $(>31 \mathrm{~S})$ was calculated. In a similar way the percentage of $\left[{ }^{3} \mathrm{H}\right] \mathrm{DNA}$ with a density $>1.716 \mathrm{~g} / \mathrm{cm}^{3}$ was calculated from centrifugation of the samples in $\mathrm{CsCl}$ gradients. The ratio of incorporation of mutant (ts) to wild type (wt) at time zero was set at 1.00 .

$39.5^{\circ}$, pulse-chase experiments were performed. Wild-type- or H5ts125-infected $\mathrm{KB}$ cells were incubated at $32^{\circ}$ and labeled for $12 \mathrm{~min}$ at $32^{\circ}$ with $\left[{ }^{3} \mathrm{H}\right]$ thymidine during the period of active viral DNA replication. The radioactive label was then chased at $39.5^{\circ}$. DNA samples, obtained directly after the pulse and at different times during the chase were analyzed by sedimentation in neutral sucrose gradients (Fig. 4).

In DNA isolated immediately after the pulse, $50-60 \%$ of the label sedimented as replicating intermediates ahead of the marker. During the chase the replicating DNA disappears and the amount of mature $31 \mathrm{~S}$ DNA increased markedly. The flow of label from fast sedimenting to $31 \mathrm{~S}$ DNA occurred at an equal rate in wild-type- and H5ts125-infected cells (Fig. 5B). The samples were also analyzed in $\mathrm{CsCl}$ density gradients and the percentage of label in dense replicating intermediates was calculated (Fig. 5A). Also according to this method of analysis, replicating DNA in a mutant-infected cells was converted into mature viral DNA similarly to wild-type DNA.

The methods used in the experiments described above are based upon the singlestranded character of replicating adenovirus DNA. From these results it cannot be concluded that single-strand breaks or small gaps are still present in mutantinfected cells after the shift-up in temperature, due to incomplete ligation of $12 \mathrm{~S}$ "Okazaki"'-pieces (Vlak et al., 1975). To test this possibility, the viral DNA from cells 60 min after the chase was analyzed under alkaline conditions. Cells were mixed with ${ }^{32} \mathrm{P}$-labeled Ad5-DNA and lysed on top of an alkaline sucrose gradient. The results show (Fig. 6) that the DNA was free of single-stranded breaks and sedimented at the same position as the genome-length marker DNA. A similar result was obtained with wild-typeinfected cells. It is therefore concluded that the DNA completed at $39.5^{\circ}$ in $\mathrm{H} 5$ ts 125 -

TABLE 2

Hybridization of H5ts125 DNA Synthesized at $32^{\circ}$ OR $39.5^{\circ}$ WITH SEParated Viral DNA STRANDS ${ }^{\alpha}$

\begin{tabular}{lccc}
\hline $\begin{array}{c}{ }^{3} \mathrm{H}-\mathrm{DNA} \\
\text { in } \\
\text { solution }\end{array}$ & $\begin{array}{c}\text { Radio- } \\
\text { activity } \\
\text { (dpm } \\
\text { input) }\end{array}$ & \multicolumn{2}{c}{$\begin{array}{c}\text { Hybridization } \\
\text { with }\end{array}$} \\
\cline { 4 - 5 } & & $\begin{array}{c}\text { H- } \\
\text { strand } \\
(\%)\end{array}$ & $\begin{array}{c}\text { L- } \\
\text { strand } \\
(\%)\end{array}$ \\
\hline H5ts125, $32^{\circ}$ & 13,025 & 11.2 & 10.7 \\
H5ts125, $39.5^{\circ}$ & 4,175 & 12.9 & 9.8 \\
Wild type, $39.5^{\circ}$ & 21,750 & 12.7 & 12.0 \\
\hline
\end{tabular}

${ }^{a}\left[{ }^{3} \mathrm{H}\right] \mathrm{DNA}$ was isolated from AGMK cells infected for $40 \mathrm{hr}$ at $32^{\circ}$ and subsequently labeled with $\left[{ }^{3} \mathrm{H}\right.$ thymidine for $4 \mathrm{hr}$ at $32^{\circ}$ or for $2 \mathrm{hr}$ at $39.5^{\circ}$, beginning half an hour after a shift-up in temperature. The amount of viral DNA synthesized at $39.5^{\circ}$ in mutant-infected cells was $9 \%$ of that in wild-typeinfected cells. The DNA was further purified by buoyant density equilibrium centrifugation in $\mathrm{CsCl}$ and $0.25 \mu \mathrm{g}$ in $1 \mathrm{ml}$ was incubated with nitrocellulose filters containing $0.25 \mu \mathrm{g}$ of $\mathrm{H}$ - or L-strand Ad5-DNA. The $\mathrm{H}$-strand is defined as the heavy strand in alkaline $\mathrm{CsCl}$. The hybridization is expressed as percentage of input [ $\left.{ }^{3} \mathrm{H}\right] \mathrm{DNA}$. 


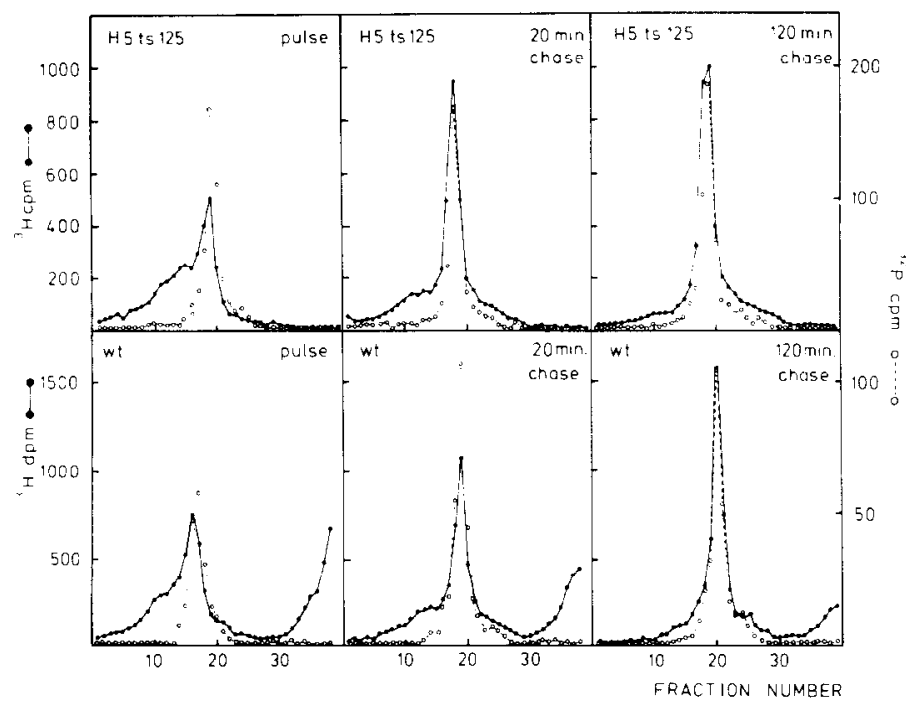

Fig. 4. Sucrose gradient sedimentation analysis of viral DNA pulse-labeled at $32^{\circ}$ and chased at $39.5^{\circ}$. $\mathrm{H} 5 \mathrm{ts} 125$ or wild-type-infected $\mathrm{KB}$ cells were incubated at $32^{\circ}$ for $40 \mathrm{hr}$ and labeled for $12 \mathrm{~min}$ at $32^{\circ}$ with $\left[{ }^{3} \mathrm{H}\right]$ thymidine. The radioactive label was then chased at $39.5^{\circ}$ (see Materials and Methods), and DNA was isolated either immediately after the pulse or at different times during the chase. ${ }^{32} \mathrm{P}$-labeled Ad5-DNA was added, and the samples were analyzed by sucrose gradient centrifugation for $16 \mathrm{hr}$ at $25,000 \mathrm{rpm}$ at $4^{\circ}$ in an $\mathrm{SW}$ 41 rotor. Sedimentation was from right to left. In the case of $\mathrm{H} 5 \mathrm{ts} 125$, fractions were precipitated with TCA and counted (cpm). The fractions from gradients containing wild-type DNA were counted directly and expressed as $\mathrm{dpm}$. The total amount of label increased 1.7-fold between the pulse and the 120-min chase in H5ts 125 -infected cells and 1.6-fold in wild-type-infected (wt) cells.

infected cells is indistinguishable by these criteria from wild-type DNA.

Although these results strongly indicate that chain propagation is not impaired at the nonpermissive temperature, it might be argued that inactivation of the $\mathrm{H} 5 \mathrm{ts} 125$ gene product is slow. It is possible that replication rounds are completed before inactivation of the protein has occurred. To investigate this possibility, cells were pulse-labeled for $10 \mathrm{~min}$ at $39.5^{\circ}, 60 \mathrm{~min}$ after the shift to that temperature. At that moment the DNA synthesis is already strongly inhibited. The pulse-label was chased at $39.5^{\circ}$, and the DNA was analyzed as described above. The results, summarized in Figs. $5 \mathrm{C}$ and $\mathrm{D}$, show that also under these conditions replicating DNA was converted to mature DNA at about the same rate in wild-type- and H5ts125infected cells. Some slower-sedimenting DNA (18-22 S), consisting partly of viral and partly of cellular DNA, was also observed in this experiment, but the amount of this material did not change during the chase, in contrast to fast sedimenting DNA or $31 \mathrm{~S}$ DNA. It is concluded that even under conditions where the H5ts125 gene function was already inactivated, chain propagation could occur normally.

\section{Density Labeling of H5ts125 Infected Cells with Bromodeoxyuridine at $39.5^{\circ}$}

From the results presented above it appears that replicating molecules are completed at the nonpermissive temperature and that reinitiation of replicated molecules is a scarce event. The latter hypothesis was tested by density labeling experiments. H5ts125- or wild-type-infected cells were maintained at $32^{\circ}$ for $40 \mathrm{hr}$ followed by $8 \mathrm{hr}$ at $39.5^{\circ}$ in the presence of bromodeoxyuridine and $\left[{ }^{3} \mathrm{H}\right]$ thymidine. Viral DNA was isolated and found to consist of more than $90 \%$ of $31 \mathrm{~S}$ molecules, with only a small amount of fast-sedimenting material. Analysis in $\mathrm{CsCl}$ density gradients (Fig. 7) showed that DNA of hybrid (H-L) and heavy $(\mathrm{H}-\mathrm{H})$ density was present in wild-type-infected cells at $39.5^{\circ}$ and in 


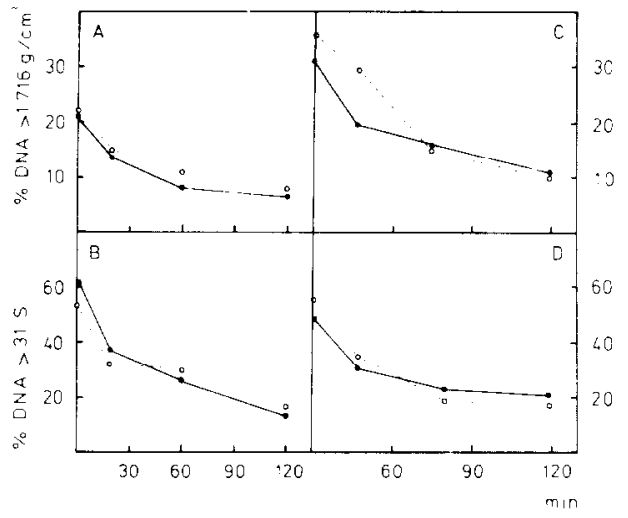

Fig. 5. Decrease in the relative amount of replicating intermediates during a chase at $39.5^{\circ}$ of viral DNA, pulse-labeled at $32^{\circ}(\mathrm{A}, \mathrm{B})$ or $39.5^{\circ}$ (C,D). H5ts125 (- ) - or wild-type $(O-O)$-infected $\mathrm{KB}$ cells were incubated for $40 \mathrm{hr}$ at $32^{\circ}$. The cultures were labeled with $\left[{ }^{3} \mathrm{H}\right.$ ] thymidine for $12 \mathrm{~min}$ at $32^{\circ}$ (A, B) or for $10 \mathrm{~min}$ at $39.5^{\circ}, 1 \mathrm{hr}$ after a shift from 32 to $39.5^{\circ}$ (C, D). The radioactive label was chased, starting at $t=0$ for various time periods. DNA was isolated and analyzed by $\mathrm{CsCl}$ density centrifugation $(A, C)$ or sucrose gradient sedimentation $(B, D)$ in the presence of ${ }^{32} \mathrm{P}$-labeled marker DNA. From the gradient profiles the amount of replicating intermediates, expressed as percentage of total viral DNA sedimenting faster than $31 \mathrm{~S}$ or having a density higher than $1.716 \mathrm{~g} / \mathrm{cm}^{3}$, was calculated.

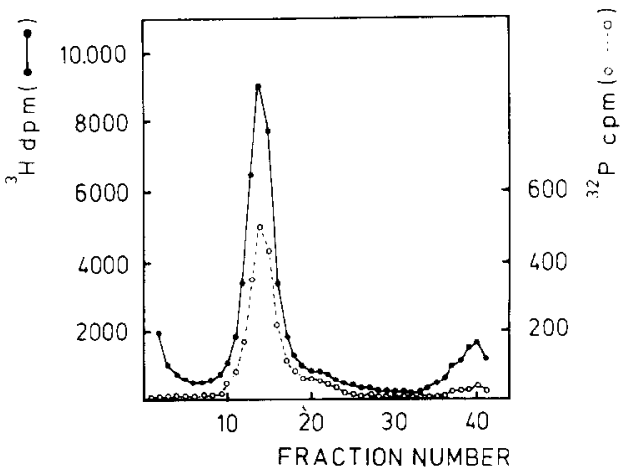

Fig. 6. Alkaline sucrose gradient analysis of H5ts125 DNA pulse-labeled at $32^{\circ}$ and chased at $39.5^{\circ}$. H5ts 125 -infected AGMK cells were labeled for $12 \mathrm{~min}$ at $32^{\circ}$ with $\left[{ }^{3} \mathrm{H}\right]$ thymidine and chased at $39.5^{\circ}$. After $60 \mathrm{~min}$ the cells were washed and suspended in $0.2 \mathrm{ml}$ of $0.01 M$ Tris/0.01 $M$ EDTA, pH 7.5. ${ }^{32} \mathrm{P}$-labeled Ad5-DNA was added and the cells were mixed with an equal volume of $0.3 M \mathrm{NaOH} / 1 M$ $\mathrm{NaCl} / 0.01 M$ EDTA $2 \%$ SDS on top of a $5-27 \%$ isokinetic sucrose gradient containing $0.3 M \mathrm{NaOH}$ and a $0.5-\mathrm{ml}$ cushion of $\mathrm{CsCl}\left(1.700 \mathrm{~g} / \mathrm{cm}^{3}\right)$. After 30 $\mathrm{min}$ the lysed cells were centrifuged for $16 \mathrm{hr}$ at $10^{\circ}$ at $25,000 \mathrm{rpm}$ in an SW 41 rotor. Fractions were collected and counted.
H5ts125-infected cells at the permissive temperature. The first appearance of heavy DNA took about $3 \mathrm{hr}$ to occur at $32^{\circ}$, which is much longer than the time required to replicate one Ad-DNA molecule. This indicates the existence of a pool of light (thy mine-containing) DNA from which molecules were randomly picked to replicate and which was only slowly filled with $\mathrm{H}-\mathrm{L}$ molecules.

No heavy DNA was observed in H5ts125infected cells at $39.5^{\circ}$. Instead, the DNA banded between the light and hybrid position with a peak at $1.742 \mathrm{~g} / \mathrm{cm}^{3}$ (Fig. 7). This result is consistent with the notion that replicating molecules complete their replication round at $39.5^{\circ}$, thereby incorporating bromouracil in the remaining part of the daughter strands to be replicated. The absence of reinitiation in these replicated molecules, although in agreement with an initiation block in $\mathrm{H} 5 \mathrm{ts} 125$ at $39.5^{\circ}$, might also be caused by the de-

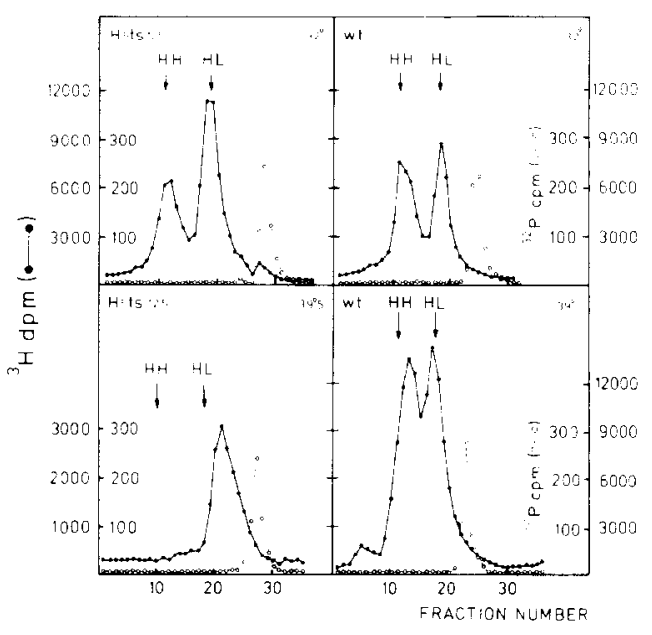

Fig. 7. CsCl density gradient centrifugation of H5ts 125 or wild-type (wt) DNA labeled with 5-bromodeoxyuridine at $39.5^{\circ}$. H5ts125- or wild-type-infected AGMK cells were incubated for $40 \mathrm{hr}$ at $32^{\circ}$, followed by a shift to $39.5^{\circ}$ in half of the cultures. After $30 \mathrm{~min}$ the cells received 5-bromodeoxyuridine $\left(10^{-5} \mathrm{M}\right)$, 5 -fluorodeoxyuridine $\left(10^{-6} \mathrm{M}\right)$ and $\left[{ }^{3} \mathrm{H}\right]$ thymidine $(2$ $\left.\mu \mathrm{Ci} / \mathrm{ml}, 4 \times 10^{-8} \mathrm{M}\right)$. Incubation was continued for 8 hr at 32 or $39.5^{\circ}$. Viral DNA was analyzed in $\mathrm{CsCl}$ density gradients in the presence of ${ }^{32} \mathrm{P}$-labeled Ad5DNA. The positions of viral DNA containing bromouracil in one strand ( $\mathrm{HL}, \rho=1.752 \mathrm{~g} / \mathrm{cm}^{3}$ ) or both strands $\left(\mathrm{HH}, \rho=1.788 \mathrm{~g} / \mathrm{cm}^{3}\right)$ were calculated from the refractive indexes. 
creased chance of reinitiating an $\mathrm{H}-\mathrm{L}$ molecule in the large pool of L-L molecules. Another possible explanation of these results is that the instability of the H5ts 125 DNA binding protein in turn unstabilizes viral DNA, resulting in excision and repair of the viral genome later after the shift in temperature. This repair synthesis may thus account for the prolonged low level of DNA synthesis at $39.5^{\circ}$.

\section{Characteristics of Viral DNA Synthesized in H5ts36-Infected Cells After Shift- $u p$}

As shown in Fig. 2, H5ts36 is a DNAdefective mutant that responds very slowly to a shift to the nonpermissive temperature. For a characterization of the viral DNA synthesized after a shift-up, we have determined the amount of labeled replicative intermediate in $\mathrm{H} 5 \mathrm{ts} 36$-infected cells after $30 \mathrm{~min}$ of incubation in the presence of $\left[{ }^{3} \mathrm{H}\right]$ thymidine at different times after the shift to the restrictive temperature. Wild-type-infected cells were pulse-labeled under identical conditions. The pulselabeled DNA was isolated, subjected to $\mathrm{CsCl}$ density gradient centrifugation and the amount of labeled material banding heavier than mature Ad5-DNA was estahlished (Table 3). No significant difference between the amounts of replicating DNA in wild-type- or H5ts36-infected cells was observed at any time after the shift-up. This indicates that no extensive inhibition of elongation occurs in $\mathrm{H} 5 \mathrm{ts} 36$-infected cells, as was also found for H5ts125-infected cells. The absence of accumulation of replicating DNA suggests that $\mathrm{H} 5 \mathrm{ts} 36$ may also be defective in initiation of replication. Pulse-chase experiments to confirm this notion are not appropriate in this case since the time to inactivate the H5ts 36 gene product is far beyond the replication time. Density labeling experiments, similar to those described for H5ts125, showed the absence of material heavier than hybrid density under conditions where wildtype-infected cells synthesized $\mathrm{H}-\mathrm{H}$ DNA (data not shown).

\section{DISCUSSION}

In this paper we have presented evidence showing that the $\mathrm{H} 5 \mathrm{ts} 125$ gene product of
TABLE 3

Amount of Replicating DNA in H5ts36- oR Wild-Type-Infected Cells at Various Times After INCUBATION AT 32 AND $39.5^{\circ 0}$

\begin{tabular}{cccccc}
\hline \multirow{2}{*}{$\begin{array}{c}\text { Time } \\
\text { after } \\
\text { shift-up } \\
\text { to } 39.5^{\circ} \\
\text { (hr) }\end{array}$} & \multicolumn{2}{c}{ wt } & & \multicolumn{2}{c}{ H5ts36 } \\
\cline { 2 - 3 } \cline { 5 - 6 } & $32^{\circ}$ & $39.5^{\circ}$ & & $32^{\circ}$ & $39.5^{\circ}$ \\
\hline 2 & 25 & 26 & & 23 & 28 \\
4 & 23 & 17 & & 18 & 21 \\
12 & 18 & 21 & & 18 & 20 \\
\hline
\end{tabular}

${ }^{a}$ AGMK cells were infected at $32^{\circ}$ for $44 \mathrm{hr}$ and then shifted to $39.5^{\circ}$ or maintained at $32^{\circ}$. Cells were labeled for $30 \mathrm{~min}$ with $\left[{ }^{3} \mathrm{H}\right]$ thymidine; at the time indicated DNA was isolated and centrifuged in $\mathrm{CsCl}$ density gradients in the presence of ${ }^{32} \mathrm{P}$-labeled Ad5DNA and the percentage of $\left[{ }^{3} \mathrm{H}\right] \mathrm{DNA}$ with a density greater than $1.716 \mathrm{~g} / \mathrm{cm}^{3}$ was calculated.

Ad5 is required for the initiation of viral DNA replication and not for chain propagation or ligation of small "Okazaki-like" pieces (Okazaki et al., 1968; Vlak et al., 1975) to unit-length DNA. DNA synthesis in $\mathrm{KB}$ or AGMK cells, shifted from 32 to $39.5^{\circ}$, does not stop immediately, but inhibition is observed after $15-30 \mathrm{~min}$, which is close to the time required for completion of one round of Ad5-DNA replication (Pearson and Hanawalt, 1971). Such a behavior is expected for an initiation mutant, assuming that the time required to inactivate the thermosensitive gene product is short. A similar conclusion was reached for H5ts 125 and H5ts149 by Ginsberg et al. (1974).

From pulse-chase experiments we conclude that the rate of chain propagation is not decreased in $\mathrm{H} 5 \mathrm{ts} 125$-infected cells at $39.5^{\circ}$. This conclusion has further been substantiated by the observation that viral DNA synthesis in isolated nuclei, obtained from $\mathrm{H} 5$ ts 125 -infected cells, did not differ in thermosensitivity from wild type. In such a nuclear system, replicating Ad5DNA molecules can be completed but reinitiation of new replication rounds does not occur (van der Vliet and Sussenbach, 1972). However, when H5ts125-infected cells were first shifted to $39.5^{\circ}$ for $60 \mathrm{~min}$, followed by measurement of viral DNA synthesis in isolated nuclei, a strong inhibition was observed (van der Vliet, Zand- 
berg, and Jansz, manuscript in preparation). This confirms that the amount of replicating intermediates was largely reduced after a shift-up. Although all these data indicate that chain elongation occurs normally at $39.5^{\circ}$, it cannot be stated for sure that the $\mathrm{H} 5 \mathrm{ts} 125$ gene product is not required for chain elongation since we cannot exclude that inactivation of the H5ts125 gene product occurs only after termination of replicating molecules. Another possibility is that the H5ts125 gene product, when involved in chain growth, is stabilized or much more slowly inactivated than the $\mathrm{H} 5 \mathrm{ts} 125$ protein in an initiation complex.

The replication of adenovirus DNA is highly asynchronous. Based upon electron microscopical data, we have put forward the hypothesis that DNA replication starts at the right molecular end, copying the parental L-strand and at the same time displacing the $\mathrm{H}$-strand. This so-called displacement synthesis leads to replicating intermediates containing a single-stranded $\mathrm{H}$-strand, since the conversion of the $\mathrm{H}$ strand to a duplex (called complementarystrand synthesis) is considerably delayed (Sussenbach et al., 1972; Ellens et al., 1974). Initiation of displacement synthesis apparently requires the $\mathrm{H} 5 \mathrm{ts} 125$ gene product, but we have no evidence for a similar involvement of this protein in the initiation of the complementary-strand synthesis. A block in the initiation of the complementary-strand synthesis would lead to accumulation of single strands from parental origin. However, parental DNA, labeled for $2 \mathrm{hr}$ at $32^{\circ}$ followed by a chase at $39.5^{\circ}$ up to $10 \mathrm{hr}$, did not remain single stranded but was normally converted to mature DNA (unpublished results). This shows that initiation of complementary-strand synthesis and displacement synthesis are not necessarily linked. An indication for such a different initiation of the $\mathrm{H}$ - and L-strand synthesis was obtained previously by studying viral DNA replication after release from inhibition by hydroxyurea (Sussenbach and van der Vliet, 1973). Under those conditions, displacement synthesis but not complementary-strand synthesis occurred.
The cessation of viral DNA replication after shift-up is readily reversible, even when the synthesis of new H5ts125 protein is blocked by addition of cycloheximide. This might be explained by the presence of a large excess of ts 125 proteins, which are reversibly inactivated at $39.5^{\circ}$ and, being nonfunctional, are slowly broken down by a proteolytic process. Such a process of inactivation has been proposed for the gene products of other Ad5 temperature-sensitive mutants (Russell et al., 1974). A large excess of $\mathrm{H} 5 \mathrm{ts} 125$ protein is in agreement with a stoichiometric role in virus replication (Austin, Young and Williams, unpublished observations).

Recently we have shown that, in H5ts125-infected cells, thermosensitive DNA binding proteins are synthesized (van der Vliet et al., 1975). These proteins consist of a 72,000-MW component and a mixture of four proteins with $\mathrm{MW}$ varying from 45,000 to 50,000 . The peptide maps of each of these proteins are most compatible with the notion that the $45,000-50,000$ MW mixture consists of proteolytic breakdown products of the $72,000-\mathrm{MW}$ protein (Rosenwirth and Levine, personal communication). Thus, it is plausible that the $\mathrm{H} 5 \mathrm{ts} 125$ gene product is identical to the 72,000-MW DNA binding protein.

This early adenovirus-specific protein binds preferentially to single-stranded DNA and is synthesized in large amounts in the infected cells (van der Vliet and Levine, 1973). It is also able to bind to replicating intermediates of adenovirus DNA in vitro, presumably to the singlestranded DNA that originates as a result of chain growth. Therefore, it is somewhat surprising to find that chain propagation is not inhibited under conditions that inactivate the DNA binding properties of the $72,000-\mathrm{MW}$ protein. We can not exclude that binding to single-stranded DNA occurs in vivo without an effect on the rate of chain elongation, serving only to protect single-stranded DNA against nuclease action. The small amount of viral $20-22 \mathrm{~S}$ DNA observed during pulse-labeling after shift-up might be an indication for such a protection.

The role of the adenovirus DNA binding 
protein in initiation has still to be elucidated. It might serve to unwind the double helix at the origin since proteins that bind specifically to single-stranded DNA, like the $\mathrm{T}_{4}$ gene-32 protein, have "unwinding" properties (Alberts and Frey, 1970). The adenovirus DNA binding protein binds equally well to single-stranded adenovirus DNA as to $\phi \mathrm{X} 174$ DNA indicating the absence of sequence specificity in vitro. Although recognition of the base sequence in the origin in vivo cannot be ruled out completely, it seems more likely that specific binding to the origin is dictated by interaction with other initiation proteins. A possible candidate for this function is the $\mathrm{H} 5 \mathrm{ts} 36$ gene product. The density labeling experiments with $\mathrm{H} 5 \mathrm{ts} 36$ show the absence of a second round of replication, while no accumulation of replicating DNA was observed at the nonpermissive temperature. These results are in agreement with a block in initiation. The slow inhibition of viral DNA synthesis after a shift-up might be explained either by a pool of stable complexes of H5ts 36 protein and DNA or by slow inactivation of the protein. The latter hypothesis seems more likely since another mutant from this group, H5ts149, starts to shut off immediately after shift-up, but with slower kinetics than H5ts125. (Ginsberg et al., 1974). Analysis of this mutant or other mutants from this group will be needed to clarify this point.

DNA-minus mutants have also been isolated for Ad12 (Shiroki et al., 1972; Ledinko, 1974; Ginsberg et al., 1974) and Ad31 (Suzuki et al., 1972). These mutants may also be required for the initiation of Ad12and Ad31-DNA synthesis (Shiroki and Shimojo, 1974). Further analysis of the specific role of these gene products in the initiation of Ad5-DNA replication is now in progress.

\section{ACKNOWLEDGMENTS}

The excellent technical assistance of Miss L. G. van Dijk and Miss M. G. Kuijk is greatfully acknowledged. We are indebted to Dr. H. S. Ginsberg and Dr. J. F. Williams for their generous gifts of the mutants $\mathrm{H} 5 \mathrm{ts} 125$ and $\mathrm{H} 5 \mathrm{ts} 36$, respectively. We thank Dr. L. Philipson for providing us with a suitable batch of poly $(U, G)$ and Dr. H. S. Jansz for stimulation and critical discussions. This work was supported in part by the Netherlands Foundation for Chemical Research (SON) with financial aid from the Netherlands Organization for the Advancement of Pure Research.

\section{REFERENCES}

Alberts, B. M., and Frey, L. (1970). T4 bacteriophage gene 32: A structural protein in the replication and recombination of DNA. Nature (London) 227, 1313-1318

Aloni, Y., Winocour, E., Sachs, L., and Torten, J. (1969). Hybridization between SV40 DNA and cellular DNA's. J. Mol. Biol. 44, 333-345.

Bellett, A. J. D., and Younghusband, H. B. (1972). Replication of the DNA of chick embryo lethal orphan virus. J. Mol. Biol. 72, 691-709.

Ellens, D. J., Sussenbach, J. S., and Jansz, H. S. (1974). Studies on the mechanism of replication of adenovirus DN $\Lambda$. III. Electron microscopy of replicating DNA. Virology 61, 427-442.

Ensinger, M. J., and Ginsberg, H. S. (1972). Selection and preliminary characterization of temperature-sensitive mutants of type 5 adenovirus. $J$. Virol. 10, 328-339.

Ginsberc, H. S., Ensingeh, M. J. Kaupfman, R. S., Mayer, A. J., and Lundholm, U. (1974). Cell transformation: A study of regulation with type 5 and 12 adenovirus temperature-sensitive mutants. Cold Spring Harbor Symp. Quant. Biol. 39, 419-426 Ginsberg, H. S., Williams, J. F., Doerfler, W. H., and Shimojo, H. (1973). Proposed nomenclature for mutants of adenoviruses. J. Virol. 12, 663-664.

Horwitz, M. S., Brayton, C., and Baum, S. G. (1973). Synthesis of type 2 adenovirus DNA in the presence of cycloheximide. J. Virol. 11, 544-551.

Ledinko, N. (1974). Temperature-sensitive mutants of adenovirus type 12 defective in viral DNA synthesis. J. Virol. 14, 457-468.

Levine, A. J., van der Vliet, P. C., Rosenwirth, B., RabeK, J., Frenkel, G., and Ensinger, M. S. (1974). Adenovirus infected cell specific DNA binding proteins. Cold Spring Harbor Symp. Quant. Biol. 39, 559-566.

Okazaki, R., Okazaki, T., Sakabe, K., Sagimoto, K., Kainama, R., Sugino, A, and Iwatsuki, N. (1968) In vivo mechanism of DNA chain growth. Cold Spring Harbor Symp. Quant. Biol. 33, 129-143.

Pearson, G. D., and Hanawalt, P. C. (1971). Isolation of DNA replication complexes from uninfected and adenovirus infected cells. J. Mol. Biol. 62, 65-80.

Pettensson, U. (1973). Some unusual properties of replicating adenovirus type 2 DNA. J. Mol. Biol. 81, 521-527.

Russell, W. C., Skeilel, J. J., and Williams, J. F. (1974). Characterization of temperature-sensitive mutants of adenovirus type 5-synthesis of polypeptides in infected cells. J. Gen. Virol. 24, 247-259.

Shiroki, K., Irisawa, J., and Shimojo, H. (1972). 
Isolation and preliminary characterization of temperíture-sensitive mutants of adenovirus 12 . Virology 49, 1-11.

ShIRoki, K., and Shimojo, H. (1974). Ananysis of adenovirus 12 temperature-sensitive mutants defective in viral DNA replication. Virology 61, 474-485.

Sussenbach, J. S., and van der Vliet, P. C. (1972). Viral DNA synthesis in isolated nuclei from adenovirus infected KB cells. FEBS Letters. 21, 7-10.

Sussenbach, J. S., van der Vliet, P. C., Ellens, D. J., and JANSZ, H. S. (1972). Linear intermediates in the replication of adenovirus DNA. Nature New Biol. 239, 47-49.

Sussenbach, J. S., and van der Vliet, P. C. (1973). Studies on the mechanism of replication of adenovirus DNA. I. The effect of hydroxyurea. Virology 54, 299-303.

Sussenbach, J. S., Ellens, D. J., and Jansz, H. S. (1973). Studies on the mechanism of replication of adenovirus DNA. II. The nature of single-stranded DNA in replicative intermediates. .J. Virol. 12, 1131-1138.

Suzuki, E., Shimojo, H., and Moritsugu, Y. (1972). Isolation and preliminary characterization of temperature-sensitive mutants of adenovirus 31 . Virology 49, 426-438.

Tinnetts, G. C., Pettersson, U., Joliansson, K., and Philipson, L. (1974). Relationship of an RNA from productively infected cells to the complementary strands of adenovirus type 2 DNA. J. Virol. 13, 370-377.

van der Eb, A. J., van Kesteren, L. W., and van
Bruggen, E. F. J. (1969). Structural properties of adenovirus DNA's. Biochim. Biophys. Acta 182, 530-541.

VAN DER EB, A. J. (1973). Intermediates in type 5 adenovirus DNA replication. Virulogy 51, 11-23.

van der Vliet, P. C., and Sussenbach, J. S. (1972). The mechanism of adenovirus DNA synthesis in isolated nuclei. Eur. J. Biochem. 30, 584-592.

VAN DER Vliet, P. C., and Levine, A. J. (1973). DNA binding proteins specific for cells infected by adenovirus. Nature New Biol. 246, 170-174.

van Der Vliet, P. C., Levine, A. J., Ensinger, M. S., and Ginsberg, H. S. (1975). Thermolabile DNA binding proteins from cells infected with a temperature-sensitive mutant of adenovirus defective in viral DNA synthesis. J. Virol. 15, 348-354.

Vlak, J. M., RoziJn, Th. H., and Sussenbach, J. S. (1975). Studies on the mechanism of replication of adenovirus DNA. IV. Discontinuous DNA chain propagation. Virology 63, 168-175.

Williams, J. F., Young, H., and Austin, P. (1974). Genetic analysis of human adenovirus type 5 in permissive and non-permissive cells. Cold Spring Harbor Symp. Quant. Biol. 39, 427-437.

Wit.kif, N. M., Ustackifri, S., and Wilitams, J. F. (1973). Characterization of temperature-sensitive mutants of adenovirus type 5: Nucleic acid synthesis. Virology 51, 499-503.

Yamashita, T., and Green, M. (1974). Adenovirus DNA replication. I. Requirement for protein synthesis and isolation of nuclear membrane fractions containing newly synthesized viral DNA and proteins. J. Virol. 14, 412-420. 